Journal of Research in Interprofessional

Practice and

Education

Vol. 4.2

November 2014

\title{
Community Partnership Interprofessional Program as Pedagogy: Process Outcomes and Faculty Impressions
}

\author{
Mary Ann Littleton, PhD.; Ken Silver, D.Sc., S.M.; \\ Susan M. Grover, PhD, RN; Rachel K. Ward, MPH, DrPH; \\ Randy L. Byington, Ed.D., MB; \& Joseph A. Florence, MD
}

\begin{abstract}
Background: Since 1992, East Tennessee State University (ETSU) has augmented traditional health professions curricula with community-based, experiential learning through the Community Partnership Interprofessional Rural Health Program. The program was expanded in 2005 by including more interprofessional faculty, students, and community partners. Interprofessional teams of students and faculty work with community organizations to identify health needs and assets and implement health education programs or services.

Methods and Findings: Course process outcomes were compiled from a survey of section reports and presentations. Faculty impressions of being involved in the course were gathered through conducting interviews with five interprofessional faculty. From 2005-2011, community partners included individuals, groups, and organizations within seven counties in Tennessee. Forty programs and services have been implemented through the program during the past seven years. Faculty reported the main reasons for being involved are their interests in interprofessional education and working in communities. Faculty also cited 12 different types of teaching strategies (pedagogical approaches) employed through the course.

Conclusions: The Community Partnership Interprofessional Rural Health Program at ETSU is a testing ground for the unique combination of communitybased learning and interprofessional health education. Study findings demonstrate how the course has benefited faculty, students, and communities.

Keywords: Interprofessional education; Community-based projects; Rural health; Appalachia
\end{abstract}

\section{Introduction}

Since 1992, East Tennessee State University (ETSU) has augmented traditional health professions curricula with community-based, experiential learning through the Community Partnership Interprofessional Rural Health Program, previously titled Interdisciplinary Rural Health Track [1-3]. Catalyzed by a grant from the W.K. Kellogg Foundation, community-academic partnerships were initially formed two decades ago to provide teaching and learning venues for medical, nursing, and public health students. Since 2005, the program has expanded to include more interprofessional faculty and students in additional community sites. Five colleges within the Academic Health Science Center (Clinical and Rehabilitative Health Sciences, Medicine, Nursing, Pharmacy, and Public Health), Psychology, and Social Work are involved in a two-semester interprofessional course, referred as the "Rural Track." The Rural Track program is directed by an Interdisciplinary Curriculum Committee 
2

Community Partnership Interprofessional Program as Pedagogy

Littleton, Silver, Grover, Ward, Byington, \& Florence

Journal of Research in Interprofessional Practice and Education

Vol. 4.2 November 2014
(ICC) with representation from each academic program involved, which meets monthly to discuss course curricular needs, plan course activities, and evaluate outcomes [1]. The two-semester course sequence includes community health needs assessment activities in the first semester and the implementation and evaluation of a community-based project in the second.

Interprofessional student teams are formed during the first semester course and consist of a mix of six to eight undergraduate nursing, social work, and respiratory therapy students, and graduate-level medical, public health, and psychology students. Teams are guided by two or more interprofessional faculty within seven different community sites. The first semester course outcomes are focused on building rapport with community partners and working to identify community health needs and assets. At the end of the first semester, interprofessional student teams present qualitative and quantitative assessment data collected throughout the semester and present preliminary plans for implementing a health promotion project. During the following semester in the second course, the same interprofessional teams finalize project plans, then implement and evaluate a health promotion or service intervention.

For both courses, learning objectives are assessed through self-directed didactic online modules linked to written assignments covering pertinent community-based topics, methods, and conceptual models (i.e., community-based participatory research, epidemiology, planning and evaluation of community-based programs and services, and leadership and ethics). Through interaction with community partners and primary populations, course material is readily applied to achieve course objectives of building community partnerships through assessment, planning, and evaluation activities, culminating in written and oral reports describing project results. Objectives for interprofessional team-building, collaboration, and communication are also emphasized. This is the first opportunity many students have to delineate the functions and roles of their profession (or college major) in relation to other health professions.

Attention to socioeconomic, cultural, and political factors is strongly encouraged throughout the two-course sequence. ETSU and its community partners are located in rural Appalachia, a region that has been beset by well-documented disparities in health outcomes associated with persistent injurious exposures and limited access to healthcare for generations [4-5]. Students and faculty within the Rural Health Program have a commitment to rural community health practice. In addition, many students enrolled in the program are from the area, thereby helping interprofessional teams easily navigate issues of cultural competence.

Community-based participatory research (CBPR) is defined as a collaborative approach to research that strives to equally involve community members and organizational representatives in all aspects of the research process [6-7]. Within the twocourse sequence, CBPR is combined with community-based learning. Student-team contribution, learning, and involvement are fundamental to community-based research activities. This model follows Israel's definition of CBPR, which is conducted with "community as a social and cultural entity with the active engagement and influence of community members in the process" [6]. The faculty role primarily involves providing contacts and context, as well as guidance and instruction to inter- 
3

Community Partnership Interprofessional Program as Pedagogy

Littleton, Silver, Grover, Ward, Byington, \& Florence

Journal of Research in Interprofessional Practice and Education

Vol. 4.2 November 2014 professional students, who for those moving from a clinical to a community focus, CBPR represents a paradigm shift.

Interprofessional education (IPE) is now at the forefront of health education curricula design with the Lancet Commission report articulating the need to rethink health professional education [8]. A focus on transformative education that develops leaders as system change agents is called for, with an emphasis on interdependence in education that breaks down the traditional silo approach of academic institutions [8]. Multidisciplinary collaboration has long been heralded as the most promising approach for developing innovative ideas, breakthroughs, and better outcomes [9-10]. However, the first step in the process is creating the setting for such encounters to happen. The ETSU's Community Partnership Interprofessional Rural Health Program (Rural Track) is one such testing ground for such developments. Elucidating our process and pedagogical findings over the past seven years may be helpful to health educators broadly as the movement for interprofessional education gains momentum. The purpose of the present study is to describe the course process outcomes from 2005-2011 and investigate course pedagogical components through faculty interviews.

\section{Methods}

A course faculty member uninvolved with teaching at the time was designated to evaluate the program for the present study, and carried out all research methods in consultation with the Interdisciplinary Curriculum Committee (ICC), including compilation of program process measures, data collection, and analysis of faculty interviews. Study methods were approved by the ETSU Institutional Review Board.

To describe the course process outcomes, a survey of community section reports and presentations was conducted to document types of community partners, primary populations partnered with, topics covered, project sites, assessment methods utilized, and projects or services from 2005-2011 at the different sites. This information is summarized in tabular form in the results section.

Important pedagogical components of the course were gathered through conducting interviews with interprofessional faculty teaching in the program. Five faculty interviews were conducted in November 2011. Faculty from public health, medicine, nursing, psychology, and respiratory therapy representing different course sections were interviewed. All interviews were conducted face-to-face on the ETSU campus depending on the preference of the person interviewed, except one interview was done via email. Interviews lasted from 1 to 2 hours. Faculty were asked the following questions: 1) How long have you been involved in the rural track program? 2) What sections did you primarily work in? 3) What were your main interests for being involved in the course? 4) What were your overall impressions of teaching the course? 5) What did you feel was the most important aspect of the course from the perspective of a faculty member? 6) What did you feel was most important about the course for students? 7) What did you feel was most important about the course for communities? 8) What was your general approach or philosophy for teaching the course? 9) What were some of the major challenges for the course? 9) What are your suggestions for improving the program? 
4

Community Partnership Interprofessional Program as Pedagogy

Littleton, Silver, Grover, Ward, Byington, \& Florence

Notes were taken during the interviews and used directly after the interview to develop a write-up or transcript of each interview, which was then sent to the individual faculty members interviewed for corrections and additions. Transcript information was sorted by question using basic text software as a means to compile information. Then information was summarized and themes within the compiled data were identified when found useful for categorizing data. Through analysis of the interview data, three main reasons or themes were identified for why faculty were involved in the course and 12 different pedagogical techniques used by faculty when teaching the course were uncovered. Qualitative data from interviews represent a narrative approach [11] to describing important pedagogical perspectives that emerged from faculty interviews. Study results were presented to faculty at a faculty development session for their input and comments.

\section{Findings}

From 2005-2011 the number of rural communities participating in the course expanded from three to seven, with over 15 faculty and 50 students participating per semester. Faculty and students from medicine, nursing, public health, clinical rehabilitative sciences, psychology, pharmacy, and social work have been represented in the program.

Table 1

\section{Primary populations, health topics, and assessment methods utilized}

\begin{tabular}{|l|l|l|}
\hline Primary populations & Topics & Assessment methods utilized \\
\hline Adults (rural white, African American, and Hispanic) & Smoking cessation and prevention & Windshield surveys \\
\hline Adults managing diabetes (African American and Hispanic) & Breastfeeding & Key informant interviews \\
\hline Children (rural white) & Diabetes prevention and management & Individual case studies \\
\hline Senior citizens groups (rural white) & Nutrition & Focus groups \\
\hline Adolescents (rural white, African American) & Obesity prevention & Community-based surveys \\
\hline Hispanic and migrant groups & Disaster preparedness & Clinic-based surveys \\
\hline Veterans & Pandemic flu & School-based surveys \\
\hline & Cancer & Photovoice \\
\hline & Interpreter services for Hispanic population & \\
\hline & Environmental and occupational health in migrant population & \\
\hline & School-based immunization & \\
\hline & Memory loss and aging & \\
\hline & Adolescent mental health & \\
\hline & Teen pregnancy & \\
\hline
\end{tabular}

From 2005-2011, community partners included individuals, groups, and organizations within seven counties in Northeast Tennessee (Carter, Cocke, Greene, Hawkins, Johnson, Unicoi, and Washington counties). These partnering agencies

Journal of Research in Interprofessional Practice and Education

Vol. 4.2 November 2014 included school boards, health councils, neighbourhood associations, senior citizen centres, rural clinics, community-based clinics, hospitals, church organizations, veteran associations, community-based coalitions, after-school clubs, non-profits, and migrant and seasonal farmworker camps. Table 1 displays information for group sections by primary populations, health topics, and assessment methods utilized. 
5

Community Partnership Interprofessional Program as

Pedagogy

Littleton, Silver, Grover, Ward, Byington, \& Florence

Journal of Research in Interprofessional Practice and Education

Vol. 4.2

November 2014
Forty programs and services have been implemented through the program during the past seven years. Table 2 shows projects conducted from 2005-2011 by section.

Table 2

\section{Projects or services completed from 2005-2011*}

\begin{tabular}{|c|c|c|c|c|c|c|c|}
\hline & $\begin{array}{l}\text { Johnson } \\
\text { County, TN }\end{array}$ & $\begin{array}{l}\text { Hawkins } \\
\text { County, TN }\end{array}$ & $\begin{array}{c}\text { Hispanic } \\
\text { Community, } \\
\text { Northeast TN }\end{array}$ & $\begin{array}{c}\text { African } \\
\text { American } \\
\text { Community, } \\
\text { Greene } \\
\text { County, TN }\end{array}$ & $\begin{array}{c}\text { Unicoi County, } \\
\text { TN }\end{array}$ & $\begin{array}{l}\text { Washington } \\
\text { and Carter } \\
\text { Counties, TN }\end{array}$ & $\begin{array}{c}\text { Washington } \\
\text { and Carter } \\
\text { Counties, TN }\end{array}$ \\
\hline 2005 & $\begin{array}{l}\text { Community- } \\
\text { based disaster } \\
\text { preparedness } \\
\text { education } \\
\text { program }\end{array}$ & \begin{tabular}{|l|} 
Eldercare \\
program on \\
prescription \\
drug programs
\end{tabular} & $\begin{array}{l}\text { Hospital- } \\
\text { based } \\
\text { educational } \\
\text { program on } \\
\text { health care } \\
\text { access for } \\
\text { Hispanics }\end{array}$ & & & & \\
\hline 2006 & $\begin{array}{l}\text { School-based } \\
\text { obesity } \\
\text { prevention } \\
\text { program }\end{array}$ & $\begin{array}{l}\text { Community } \\
\text { health fair on } \\
\text { disaster } \\
\text { preparedness }\end{array}$ & $\begin{array}{l}\text { Video } \\
\text { production } \\
\text { on health } \\
\text { care access } \\
\text { for Hispanics }\end{array}$ & $\begin{array}{l}\text { Community } \\
\text { mobilization } \\
\text { dinner with } \\
\text { pastors speak- } \\
\text { ing about } \\
\text { health }\end{array}$ & $\begin{array}{l}\text { Community- } \\
\text { based senior } \\
\text { educational } \\
\text { program on } \\
\text { aging and } \\
\text { memory loss }\end{array}$ & & \\
\hline 2007 & $\begin{array}{l}\text { Community- } \\
\text { based senior } \\
\text { program on } \\
\text { obesity }\end{array}$ & \begin{tabular}{|l} 
Business \\
committee \\
development \\
pandemic flu \\
preparedness
\end{tabular} & $\begin{array}{l}\text { Diabetes } \\
\text { health screen- } \\
\text { ings and } \\
\text { education at } \\
\text { local flea } \\
\text { market }\end{array}$ & $\begin{array}{l}\text { Diabetes } \\
\text { screening and } \\
\text { educational } \\
\text { breakfast }\end{array}$ & $\begin{array}{l}\text { Extensive } \\
\text { school-based } \\
\text { youth risk } \\
\text { assessment }\end{array}$ & & \\
\hline 2008 & $\begin{array}{l}\text { Clinic-based } \\
\text { health literacy } \\
\text { educational } \\
\text { program for } \\
\text { providers }\end{array}$ & $\begin{array}{l}\text { School-based } \\
\text { five-a-day } \\
\text { nutrition } \\
\text { program }\end{array}$ & $\begin{array}{l}\text { Documentation } \\
\text { of occupa- } \\
\text { tional risks } \\
\text { for migrant } \\
\text { workers }\end{array}$ & $\begin{array}{l}\text { Community } \\
\text { dinner to } \\
\text { educate on } \\
\text { healthy } \\
\text { cooking }\end{array}$ & $\begin{array}{l}\text { School-based } \\
\text { resources and } \\
\text { information } \\
\text { for adolescent } \\
\text { mental health }\end{array}$ & $\begin{array}{l}\text { Smoking ces- } \\
\text { sation support } \\
\text { group for } \\
\text { pregnant } \\
\text { women }\end{array}$ & \\
\hline 2009 & $\begin{array}{l}\text { Community- } \\
\text { based } \\
\text { diabetes } \\
\text { prevention } \\
\text { program }\end{array}$ & $\begin{array}{l}\text { Church-based } \\
\text { cancer } \\
\text { prevention } \\
\text { and screening } \\
\text { program }\end{array}$ & $\begin{array}{l}\text { Physician } \\
\text { education } \\
\text { program on } \\
\text { migrant } \\
\text { occupational } \\
\text { hazards }\end{array}$ & $\begin{array}{l}\text { Community } \\
\text { dinner to } \\
\text { motivate for } \\
\text { healthy } \\
\text { lifestyles }\end{array}$ & $\begin{array}{l}\text { Piloted school- } \\
\text { based adoles- } \\
\text { cent mental } \\
\text { health advo- } \\
\text { cacy website }\end{array}$ & $\begin{array}{l}\text { Clinic-based } \\
\text { video interven- } \\
\text { tion for } \\
\text { pregnant } \\
\text { smokers }\end{array}$ & $\begin{array}{l}\text { Breastfeeding } \\
\text { education for } \\
\text { expectant } \\
\text { mothers }\end{array}$ \\
\hline 2010 & $\begin{array}{l}\text { School-based } \\
\text { immunization } \\
\text { educational } \\
\text { program }\end{array}$ & $\begin{array}{l}\text { Church-based } \\
\text { cancer aware- } \\
\text { ness fair }\end{array}$ & $\begin{array}{l}\text { Community- } \\
\text { based occupa- } \\
\text { tional hazards } \\
\text { assessment }\end{array}$ & $\begin{array}{l}\text { After-school } \\
\text { program to } \\
\text { promote } \\
\text { healthy } \\
\text { nutrition } \\
\text { and exercise }\end{array}$ & $\begin{array}{l}\text { School-based } \\
\text { Facebook page } \\
\text { for adolescent } \\
\text { health } \\
\text { advocacy }\end{array}$ & $\begin{array}{l}\text { School-based } \\
\text { adolescent } \\
\text { smoking } \\
\text { cessation and } \\
\text { prevention } \\
\text { program }\end{array}$ & $\begin{array}{l}\text { School-based } \\
\text { breastfeeding } \\
\text { awareness } \\
\text { program for } \\
\text { adolescents }\end{array}$ \\
\hline 2011 & $\begin{array}{l}\text { Community } \\
\text { organizing to } \\
\text { address high } \\
\text { teen preg- } \\
\text { nancy rates }\end{array}$ & $\begin{array}{l}\text { Development } \\
\text { of a cancer } \\
\text { resource } \\
\text { directory }\end{array}$ & $\begin{array}{l}\text { Comprehensive } \\
\text { assessment of } \\
\text { mental, physi- } \\
\text { cal, and health } \\
\text { care pesticide } \\
\text { exposures }\end{array}$ & $\begin{array}{l}\text { Diabetes } \\
\text { prevention } \\
\text { educational } \\
\text { event through } \\
\text { faith-based } \\
\text { communities }\end{array}$ & $\begin{array}{l}\text { Implemented } \\
\text { Solidarity } \\
\text { (anti-bullying) } \\
\text { Exercise to } \\
\text { high school } \\
\text { students }\end{array}$ & $\begin{array}{l}\text { Implemented } \\
\text { health fair to } \\
\text { alternative } \\
\text { schools }\end{array}$ & $\begin{array}{l}\text { Implemented } \\
\text { breastfeeding } \\
\text { Jeopardy } \\
\text { game in } \\
\text { high school }\end{array}$ \\
\hline
\end{tabular}

*Blank cells indicate community section was not initiated at the time 
6

Community Partnership Interprofessional Program as Pedagogy

Littleton, Silver, Grover, Ward, Byington, \& Florence
Journal of Research in Interprofessional Practice and Education

Vol. 4.2

November 2014

\section{Faculty interviews}

Faculty mentioned three main reasons for being involved in the courses: 1) interprofessional education, 2) community involvement, and 3) career alignment. Table 3 shows comments related to each theme.

\section{Table 3}

\section{Faculty quotes and comments highlighting main themes related to faculty involvement}

\begin{tabular}{|l|l|}
\hline Themes & Comments \\
\hline Interprofessional education & $\begin{array}{l}\text { •"Being part of an interprofessional team" } \\
\text { "Learning what other professions are doing" } \\
\text { "It is where the future of education is" } \\
\text { - "Rewarding to see students interact interprofessionally - } \\
\text { make a contribution to a group" }\end{array}$ \\
\hline Community & $\begin{array}{l}\text { - Opportunity to work with communities to address health issues and needs } \\
\text { - Opportunity to teach community-based participatory research } \\
\text { "Having a day devoted to community work" } \\
\text { - Offers a way to get out of the office - and branch out doing "hands on"learning } \\
\text { • Having "sacred time" in the community - just devoted to interprofessional } \\
\text { community-based education } \\
\text { "Putting your money where your mouth is - working with communities" } \\
\text { • Gauge personal experiences of rural with working with rural communities }\end{array}$ \\
\hline Career & $\begin{array}{l}\text { • Fits career path (research and advocacy interests) } \\
\text { • Potential for collaboration } \\
\text { • Potential incubator for community-based research grants }\end{array}$ \\
\hline
\end{tabular}

Faculty main impressions from being involved include the enriching interprofessional experience of the course, and how the value of IPE is realized through the course by students, faculty, and the community. One faculty member mentioned that the course teaches what he termed "practical applied idealism," where "students learn that the sky is not the limit when deciding on course activities." Related to this were other faculty comments that the course teaches students how to deal with real-life uncertainties. Faculty also remarked that, in general, students need to be selfdirected and self-motivated to realize the potential benefits from working in communities in interprofessional groups. Overall, those interviewed felt meaningful new information and community services had been realized through the program. Faculty delineated benefits for students and communities from the program. Table 4 compiles faculty quotes and comments related to these benefits.

Through interviews faculty described 12 different teaching strategies employed related to community-based and interprofessional educational methods. Table 5 provides a list of these pedagogical approaches utilized within the course. 
7

Community Partnership Interprofessional Program as Pedagogy

Littleton, Silver, Grover, Ward, Byington, \& Florence
Journal of Research in Interprofessional Practice and Education

Vol. 4.2

November 2014
Table 4

\section{Faculty perspectives on the benefits of the program for students and communities}

\begin{tabular}{|c|c|}
\hline Student benefits & Community benefits \\
\hline $\begin{array}{l}\text { - "It is a good socialization process for students from dif- } \\
\text { ferent disciplines to come and learn how to play } \\
\text { together - for them to be outside of their comfort } \\
\text { zone." } \\
\text { - "Having the community depending on them grows } \\
\text { them up." } \\
\text { - "Students get a good feel for the importance of multi- } \\
\text { ple determinants of health." } \\
\text { - "Peer-to-peer learning is important - builds leader- } \\
\text { ship skills." } \\
\text { - "Courses provide resume building." } \\
\text { - "Gives students immediate contact with future } \\
\text { employers." }\end{array}$ & $\begin{array}{l}\text { - "Helps communities define and address health issues." } \\
\text { - "Gives communities (especially the underserved) the } \\
\text { sense that someone is committed to working with } \\
\text { them over several semesters." } \\
\text { - "Lets the community see that we are interested in } \\
\text { forming partnerships with them - that we want to } \\
\text { work in a participatory manner." } \\
\text { - "Enhances ETSU and Community relationships" } \\
\text { - "Provides letters of support and grants/partnerships." } \\
\text { - "Gives communities immediate contact with future } \\
\text { workforce." } \\
\text { - "Having a commitment to CBPR - having community } \\
\text { members contribute to papers and presentations is } \\
\text { important." } \\
\text { - "Provides increased visibility to communities about } \\
\text { ETSU - helps them recruit future students." } \\
\text { - Helps encourage/break down barriers to pursuing } \\
\text { health professional degrees for those in rural } \\
\text { communities. }\end{array}$ \\
\hline
\end{tabular}

Table 5

\section{Pedagogical approaches described by faculty}

1. Interprofessional faculty model how to engage in critical discourse, helping student groups form ideas and set appropriate boundaries for developing project activities.

2. The use of dialogue to build consensus.

3. Group Inquiry Model where everyone sets the agenda.

4. Peer-to-peer learning and interpretation is an important part of the course.

5. Dialogues between students (without faculty) facilitate development of leadership skills.

6. Discovery learning - students realizing that questions and concerns of people in the community are not the same as those in the hospital bed. Forces them to see patients as individuals with families living within a community.

7. Observational learning: Asking students while at a community event "what do you see"—helps students get a community "lens" on issues.

8. Asking students to describe the issue from their profession's point of view.

9. Taking time to learn students' interests, talents, and comfort zones and matching that to their contributions.

10. Students being out of their comfort zone-interprofessional pairing on activities in teams.

11. Reflective learning: Taking time to reflect on the course activities—on the process.

12. Debriefing to help uncover student's preconceived ideas. 
8

Community Partnership Interprofessional Program as Pedagogy

Littleton, Silver, Grover, Ward, Byington, \& Florence
Journal of Research in Interprofessional Practice and Education

Vol. 4.2 November 2014
Faculty mentioned many challenges related to the course, including scheduling issues, which are a perennial problem, where trade-offs and compromises were needed across disciplines. Also, the course assessment activities occur in the spring semester and projects are implemented in the fall, creating a continuity issue with the long summer break in the middle. The need for faculty development sessions and continual course revisions are challenging in an interprofessional course. In addition, dealing with year-to-year transitions with new groups of students joining existing community relationships, and in some cases on-going projects, demands constant coordination. Faculty also said there is a need to incorporate more teaching and input from community partners. They described a need to determine the value and outcomes of the course from the community's point of view, and to understand the importance of the experience to students now and in the future. The faculty's position is best summarized by one of the interview quotes: "We need to better evaluate interprofessional and community-based education immediate and long-term outputs from such a program."

\section{Discussion}

The Community Partnership Interprofessional Rural Health Program (Rural Track) at ETSU is unique in that it not only provides an interprofessional learning opportunity for students and faculty, but it also emphasizes community-based research approaches to working in communities, especially adherence to principles of community-based participatory research [7]. From 2005-2011, forty programs and services were implemented within the two-semester course sequence. These ranged from comprehensive assessments, to health fairs, to grant-funded prevention projects. The range of priority populations, health topics, and assessment methods with diverse stakeholders and community partners demonstrates a regional commitment to an academic-community collaborative approach to teaching and learning. Many of these relationships were forged through the W.K. Kellogg Foundation Community Partnerships Grant where clinical and community-learning sites were first established in Hawkins and Johnson counties located in Appalachian Tennessee. Since 2005, the program was expanded to incorporate faculty with community-based research ties in the area, and a desire to support those connections through being involved in the courses.

Based on the faculty interviews, faculty see the courses as their main avenue for staying connected to community and pursuing research and advocacy interests in the area. Interviews with faculty emphasize how interprofessional education, community basedresearch, and service interests all intersect to make their involvement a win-win-win situation. Faculty are keenly interested in the interprofessional aspects of the course, including both teaching and research opportunities and collaborations. The course has facilitated the development of internal, regional, state, and national grant proposals, and has contributed to the field through local, regional, and national presentations and publications on course research projects from faculty and students [12-14].

Faculty often focus on how the course benefits students in practical ways such as socializing with others, seeing cultural and health determinants in action, and work- 
9

Community Partnership Interprofessional Program as Pedagogy

Littleton, Silver, Grover, Ward, Byington, \& Florence

Journal of Research in Interprofessional Practice and Education

Vol. 4.2 November 2014 ing in teams to discuss, plan, and carry-out realistic course activities. This is echoed by others as an important benefit of community-based learning and research, where students are not only accountable to their instructors, but more importantly, to community partners [15]. Team building and leadership development are natural products of the course given the collaborative nature of CBPR as it is integrated within the Rural Track.

A recent evaluation of interprofessional healthcare students' attitudes toward IPE conducted through the Queen's University Inter-Professional Patient-centered Education Directive (QUIPPED) in Canada found that medical students had less positive attitudes toward team learning compared to nursing, occupational therapy, and physical therapy students [16]. In the Rural Track, traditional health professional hierarchies are challenged as students soon learn that $4^{\text {th }}$ year undergraduate nursing and respiratory students have more hands-on clinical knowledge and experience than the $1^{\text {st }}$ year medical students, and that graduate public health and psychology students can provide leadership alongside their medical student counterparts. The QUIPPED study also pointed out the importance of choice and enthusiasm as key components to promoting IPE curriculum development [16]. This finding is aligned with faculty comments that students need to be motivated and self-starters to get the most out of the course experience.

Real-life community projects are not only hands-on approaches to communitybased learning, they also provide a unique entry to discussion teaching where the focus is less on teaching content and more on engaging students in critical thinking focused on the specific community context [17]. Educational models like the Rural Track will become more appealing as we move into educating today's "Net Generation" of savvy online users who value independence and autonomy in their learning styles and desire more active, engaged learning formats [18-19]. Within the Rural Track, students read online modules and apply the information in skill building assignments before class. They come to the community setting prepared to share and interact with their interprofessional peers, faculty, and community members, yet the real-life context allows the application of information in new and dynamic ways, and provides opportunities for spontaneous learning and teachable moments.

Perhaps the most interesting finding was the extensive list of teaching strategies employed by faculty. The types of pedagogical strategies mentioned by faculty can be classified as critical theory perspectives, group inquiry models, consensus building, discovery learning, observational learning, reflective learning, and the value of situations where students are both in and out of their comfort zones were all mentioned $[1,3,20-26]$. Though initially described as an inquiry-based model, interviews help identify a broader scope of pedagogical approaches used within the course [1]. These different approaches help students learn and apply knowledge through a variety of learning strategies.

Better communication between professionals in understanding differences and similarities is cited as an important aspect of developing collaborative health teams [27]. Faculty within the Rural Track program often are there to help bridge communication gaps that might come from misunderstandings or biases across disciplines. 
10

Community Partnership Interprofessional Program as Pedagogy

Littleton, Silver, Grover, Ward, Byington, \& Florence

Journal of Research in Interprofessional Practice and Education

Vol. 4.2 November 2014
One of the key goals of interprofessional and community-based learning is to create learning environments where group members are both teachers and learners, with shared leadership and group process that leads to innovative and effective interventions [27]. However, IPE is just starting to develop effective curriculum and evaluation strategies to determine how interprofessional groups learn best and how that learning translates into better health outcomes.

Sava, Armitage, and Kaufman have made a call for medicine to adopt the "public health system's team-based culture and rich network of community partnerships to improve health outcomes and reduce health disparities" [28]. At ETSU, with the funding of the W.K. Kellogg Community Partnerships Grant, the schools of medicine, nursing, and public health have integrated curricula to provide interprofessional community-based learning starting in 1992, and that curriculum has been refined and expanded to include more interprofessional learning opportunities within the last seven years. At its core, the curriculum uses a public health approach to assessing community needs and strengths, and working with community members to plan, implement, and evaluate health programs and services. In the present study, faculty mentioned how the course plays an important role in fostering a sense of community connection with the university and vice versa.

As expected with a course that attempts to accomplish so many goals, there are inherent challenges. Again, we are fortunate at ETSU to have had the Kellogg grant, which paved the way through what may seem like unchartable waters for many institutions [1]. One way to address the inherent challenges is through the program Interdisciplinary Curriculum Committee (ICC). Recently, we have been able to set up faculty development sessions the week before the course starts to make sure didactic and team-building aspects of the course are communicated. We also have included faculty development using epidemiology modules assisted by the Tennessee State Health Department, Division of Quality of Improvement. Further, it is now standard procedure to invite community-based interprofessional research teams at the beginning of the semester to demonstrate best practice examples of community-based interprofessional health projects in the region.

Faculty made important points about the need for more effort to be put into understanding the community impressions of the course and gathering their input. Through informal feedback from community partners, we have made efforts to provide more continuity between years, such as continuing with the same topic for several years, or implementing long-term interventions with more community and ETSU support. Our main indicator of community satisfaction is the willingness of communities year after year to partner with us. In most instances, it does take years to develop connection, trust, and creditability in communities, and we need to do better at capturing this process and gathering community input to help us evaluate the program.

We have several procedures to gather student feedback, including standard student assessments of instructions (SAIs) and student and faculty debriefings on the last day of each semester. Findings from these feedback mechanisms are compiled and discussed at ICC meetings to determine whether course objectives were met as well as 
11

Community Partnership Interprofessional Program as Pedagogy

Littleton, Silver, Grover, Ward, Byington, \& Florence
Journal of Research in Interprofessional Practice and Education

Vol. 4.2

November 2014 revisions needed. Recruitment issues cited in a previous study of the course [1] have been for the most part resolved; nonetheless, enrollment numbers vary from year to year across disciplines due to new demands or curriculum requirements. ETSU's colleges of medicine, nursing (undergraduate), and public health (MPH) have integrated the Rural Track as required courses, thereby helping to maintain a level of stability in enrollment. As faculty have cited, we need to gain a better understanding of the longterm outcomes of students involved with this course. Specifically, we need to investigate exactly how it affects their decisions on where and how they practice. IPE research is in its infancy and few long-term, rigorous studies on outcomes exist [29]. Given the expanded nature of the course at this point, and the fact that it includes communitybased public health approaches within an interprofessional learning environment, there is an even greater need to investigate long-term influences of the program.

\section{References}

1. Goodrow, B., Olive, K., Behringer, B., Kelley, M., Bennard, B., Grover, S., Wachs, J. \& Jones, J. (2001). The Community Partnerships Experience: A report of institutional transition at East Tennessee State University. Academic Medicine, 76(2), 134-141.

2. Brown, B., Behringer, B., Smith, P., Townsend, T., Wachs, J., Stanifer, \& Goodrow, B. (2003). Graduate health professions education: An interdisciplinary university - community partnership model 1996 - 2001. Education for Health, 16(2), 176-188.

3. Florence, J., \& Behringer, B. (2011). Community as a classroom: Teaching and learning public health in rural Appalachia. Journal of Public Health Management and Practice, 17(4), 316-323.

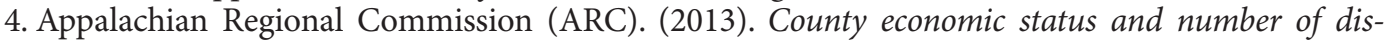

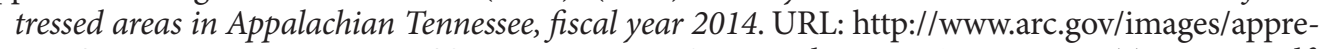
gion/economic statusFY2014/CountyEconomicStatusandDistressAreasFY2014Tennessee.pdf [December 21, 2013].

5. Appalachian Regional Commission (ARC). (2008). Underlying socioeconomic factors influencing health disparities in the Appalachian Region. Mary Babb Randolph Cancer Center/Office for

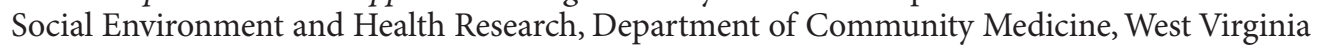

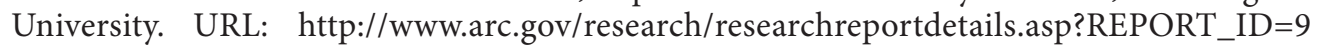
[December, 21, 2013].

6. Israel, B., Shulz, A., Parker, E., \& Becker, A. (1998). Review of community based research: Assessing partnership approaches to improve public health. Annual Review of Public Health, 19, 173-202.

7. Israel, B., Shulz, A., Parker, E., Becker, A., Allen, A., \& Guzman, J.R. (2008). Critical issues in developing and following CBPR principles. In Minkler, M., \& Wallerstein, N. (Eds.), Communitybased participatory research for health: From process to outcomes, $2^{\text {nd }}$ edition. (pp. 47-66). Hoboken, NJ: John Wiley \& Sons.

8. Frenk, J., Chen, L., Bhutta, Z.A., Cohen, J. Crisp, N., Evans, T., Fineberg, H., Garcia, P., Ke, Y., Kelley, P., Kistnasamy, B., Meleis, A., Naylor, D., Pablos-Mendez, A., Reddy, S., Scrimshaw, S., Sepulveda, J., Serwadda, D., \& Zurayk H. (2010). Health professionals for a new century: Transforming education to strengthen health systems in an interdependent world. The Lancet, 376(9756), 1923-1958.

9. Green, L. W. (2006). Public health asks of systems science: To advance our evidence-based practice, can you help get us more practice-based evidence? American Journal of Public Health, 96(3), 406-413.

10. Ness, R. (2011). Public health research priorities for the future. Public Health Reviews, 33(1), 225-239.

11. Ulin, P., Robinson, E., \& Tolley, E. (2005). Qualitative methods in public health: A field guide for applied research. San Francisco, CA: Jossey-Bass.

12. Seidel, A. K., Schetzina, K., Freeman, S., Coulter, M., \& Colgrove, B. (2013). Comparison of breastfeeding knowledge, attitudes, and beliefs before and after educational intervention for rural Appalachian high school students. Southern Medical Jounal, 106(3), 224-229. 
12

Community Partnership Interprofessional Program as Pedagogy

Littleton, Silver, Grover, Ward, Byington, \& Florence
13. Loury, S., Bradfield, M., Florence, J., Silver, K., Hoffman, K., \& Andino, A. (2013). Addressing the health of Hispanic migrant farmworkers in rural East Tennessee through interprofessional edu-

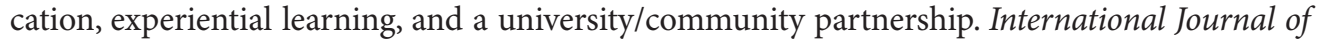
Health Sciences Education, 1(1). URL:'http://_c.etsu.edu/ijhse/vol1/iss1/3.

14. Silver, K., Hoffman, K., Loury, S., Fethke, N., Liebman, A., Manzl, N., Manock, S., Andino, A., \& Bradfield, M. (Forthcoming). A campus-community partnership for farmworkers' health: Interventions for tomato workers in Tennessee. Progress in Community Health Partnerships: Research, Education and Action.

15. Strand, K. J. (2000). Community based research as pedagogy. Michigan Journal of Community Service Learning, 7, 85-96.

16. Medeves, J., Paterson, M., Broers, T., \& Hopman, W. (2013). The QUIPPED Project: Students' attitudes toward integrating interprofessional education into the curriculum. Journal of Research in Interprofessional Practice and Education, 3(1), 3-21.

17. Barnes, L. B., Christensen, C. R., \& Hansen, A. (1994). Premises and practices of discussion teaching. In Teaching and the case method, $3^{\text {rd }}$ Edition. (pp. 23-33). Boston, MA: Harvard Business School Press.

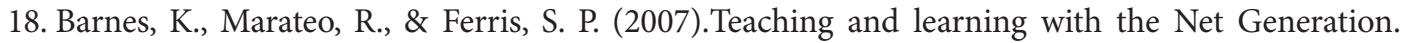

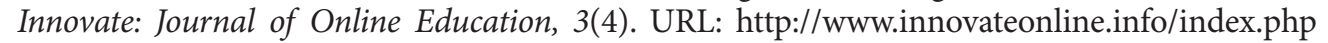

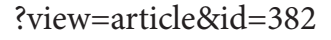

19. Tapscott, D. (1998). Growing up digital: The rise of the Net Generation. New York, NY: McGraw Hill.

20. Barkley, E., Cross, K., \& Major, C. (2004). Collaborative learning techniques in higher education: A handbook for college faculty. San Francisco, CA: Jossey Bass.

21. Innes, J., \& Booher, D. (1999). Consensus building and complex adaptive systems: A framework for evaluating collaborative planning. Journal of American Planning Association, 65(4), 412-423.

22. Bruner, J. S. (1961). The act of discovery. Harvard Educational Review, 31, 21-32.

23. Alfieri, L., Brooks, P., Aldrich, N., \& Tenenbaum, H. (2011). Does discovery-based instruction enhance learning? Journal of Educational Psychology, 103(1), 1-18.

24. Bandura, A. (1971). Psychological modeling; conflicting theories. Chicago, IL: Aldine-Atherton.

25. Brockbank, A., \& McGuill, I. (2007). Facilitating reflective learning in higher education. New York, NY: McGraw Hill.

26. Borbye, L. (2010). Out of the comfort zone: New ways to teach, learn and assess essential professional skills - an advancement in educational innovation. San Rafael, CA: Morgan and Claypool.

27. Freeth, D., Hammick, M., Reeves, S., Koppel, I., \& Barr, H. (2005). Effective interprofessional education: Development, delivery, and evaluation. Malden, MA: Blackwell Publishing.

28. Sava, S., Armitage, K., \& Kaufman, A. (2013). It's time to integrate public health into medical education and clinical care. Journal of Public Health Management Practice, 19(3), 197-198.

29. Reeves, S., Zwarenstein, M., Goldman, J., Barr, H., Freeth, D., Hammick, M., \& Koppel, I. (2008). Interprofessional education: Effects on professional practice and health care outcomes. Hoboken, NJ: Wiley \& Sons Ltd.
Journal of Research in Interprofessional Practice and Education

Vol. 4.2

November 2014 